\title{
CONFERENCIA
}

\section{O HOMEM EUCLIDES DA CUNHA (1)}

Escrever ou falar sôbre Euclides da Cunha, no mês votado às solenes comemorações da vida e obra do escritor singular. é evocar um dos maiores cultos de Francisco Venâncio Filho e oferecer-lhe à querida memória a homenagem de um quarto de século de amizade e de admiraçāo. Nenhum outro, entre tantos que se consagraram a essas práticas rituais. "por protesto e adoraçāo". foi mais fiel à memória do imortal autor d" Os Sertões" nem incarnou mais profundamente a comovida e edificante devoçāo da mocidade idealista do país à extraordinária figura do mais brasileiro de todos os escritores. Nenhum outro se empenhou tāo a fundo e com tanto calor e paixāo na penosa tarefa de redescobrir e revelar Euclides e sua vida, - pois que sua obra cruzara o espaço com a rapidez e as fulgurações de um relâmpago, - e mostrar, com a fôrça de um exemplo impressionante, o papel dos grandes homens que são a um tempo inspiradores e modelos da existência ideal. Nenhum outro, entre tantos ilustres e devotados euclideanos, se dedicou com mais zêlo e pertinácia a pesquisas de tôda ordem sôbre o homem e o escritor, o militar e o engenheiro, e coligiu e acumulou, com mais tocante solicitude, para abri-la a todos os que o procurassem, a documentaçāo indispensável à plena inteligência e reconstituiçāo da vida de Euclides. "Em Venâncio Filho (eis, entre numerosos testemunhos, o de Silvio Rabelo) encontrei o mais minucioso e o mais exato informador sôbre a figura por tantos de seus - contemporâneos descaracterizada, como é a do militar, do explorador, do correspondente de guerra, do jornalista e do escritor que foi Euclides. Era com generosa hospitalidade que Venâncio Filho me recebia na sua residência. Até quase madrugada não se cansava de falar, de revolver gavetas e armários à cata do documento ou da notação desconhecida, recompondo, com sua palavra animada, a fisionomia psicológica e moral de. Euclides, retificando erros de interpretaçāo, corrigindo enganos biográficos, precisando episó-

(1). - Conferéncia proferida a 30 de agôsto de 1951 no salão nobre da Faculdade de Filosofia, Ciências e Letras, da Universidade de São Paulo. 
dios, lembrando anedotas nem sempre bem contadas pelos que se ocuparam da vida daquele que considerava o mais genial dos escritores brasileiros" (2).

Mas a Venâncio Filho, cuja última conferência teve ainda por objeto Euclides da Cunha e que sucumbiu a 12 de agôsto de 1946 , na derradeira peregrinação religiosa, a caminho de S. José do Rio Pardo, - a Meca do euclideanismo, como lhe chamava, o que mais o comovia, nessa personalidade complexa e robusta, era realmente o aspecto humano.Admirar, admirava calorosamente Euclides, por tôdas as suas faces : na sua notável capacidade profissional; na audácia e firmeza do explorador, do tipo de um Lacerda de Almeida que, nas expressões de Euclides, foi talhado "ao molde de todos os Levingstones e de todos os Stanleys"; em sua obra que denunciava, ao primeiro contato, a originalidade e a fôrça, pela concepção e pelo estilo; na largueza de vistas, de um "técnico de idéias gerais", como a Liautey chamou André Maurois, e na órbita de cujo interêsse gravitavam todos os problemas, ainda os mais distantes de sua profissāo. Preocupado em examinar a tôdas as luzes a personalidade original, tāo vária e, à primeira vista, desconcertante, do insigne escritor, era com a alegria ingênua de uma descoberta que êle lhe encontrava um novo aspecto ou via alguêm encarar o "seu" Euclides de um ângulo novo de observaçāo. Êsse homem que, ao contrário de tantos cutros que, para empregar as próprias palavras de Euclides, "fizeram seu nome como os usurários, sua fortuna, vagarosamente, aiuntando todos os vintens dos aplausos frívolos e todos os mulambos de suas idéias esmirradas" (3), surgiu de chofre, nos deslumbramentos de uma apariçāo imprevista, parecia, aos olhos de Venâncio Filho, um mundo misterioso, capaz de trazer respostas a perguntas inesperadas e novas revelações a uma legiāo de exploradores... Mas, profundamente humano e sensivel, êle próprio, a tudo o que dignifica e exalta o homem, nāo sòmente estava certo de que Euclides nunca se conteve nem podia conter-se "na sua situaçāo de engenheiro errante, prêso pelos empreiteiros e absorvido em orçamentos" (4), como julgava ser o humano o valor supremo a que tudo se subordinava em Euclides, - a vida militar, a sua "engenharia obscura", as entradas aos sertões, a arte do escritor, as atividades e a meditação, como suas reações e atitudes em face das cousas, dos homens' e dos acontecimentos. De fato, o homem Euclides da Cunha, que mais fazia vibrar a sensibilidade de Venâncio Filho, se nāo ultra-

\footnotetext{
(2). - Sflvio IRabelo - o bom Franciseo Venancio Filho, in "O Jornal", ano XXIX. Rio de Janeiro, 16 de março de 1947.

(3). - Francisco Venfncio Filho - Euclides da Cumha a seus amigos. Carta a Vicente de Carvalho. 9 de setembro de 1904, pg. 136. Companhia Editora Nacional, São Paulo, 1.938.

(4). - Francisco Venúncio Filho - Euclides da Cunha a seus amigos. Carta a José Veríssimo. 4 de julho de 1903, pg. 102. Companhia Editora Nacional. Sāo Paulo, 1938.
} 
passou o escritor, foi certamente digno dêle, e a fonte, viva e borbulhante, inexgotável em energias e surprezas, de que constantemente se alimentou.

Nāo foi, porém, porque Venâncio Filho partilhava essa minha maneira de ver Euclides, que tomei para objeto dêste trabalho o homem que foi o famoso escritor, tāo pouco estudado sob êste aspecto. Esta conferência tem sua pequena história. Triste e dolorosa história. Conta-nos Silvio Rabelo que, ao despedir-se em uma das noites em que o visitara no Rio, em 1946, the pediu Venâncio Filho que, antes de voltar a Pernambuco, fôsse "conhecer S. José do Rio Pardo, a ponte que Euclides reconstruira sôbre o rio, o sobradinho à rua 13 de Maio, onde morara durante três anos, a barraca à sombra de uma paineira, onde escrevera tantas das páginas d" "Os Sertões", e, sobretudo, respirar o ar da cidade que era a Meca dos euclideanos". Foi êste também o último pedido que me dirigiu em S. Paulo, a 9 de agôsto de 1946, na véspera da tristíssima madrugada, em que se inicióu sua agonia e três dias antes de morrer, reiterando-me os desejos, repetidos durante sete anos, de que eu proferisse, naquela cidade, uma conferência sôbre Euclides, na augusta semana das comemorações. Se nāo me foi possivel, em vida do amigo incomparável, atender a tôda a sua vontade, em parte independente da minha, nāo podia faltar ao sagrado compromisso, confirmado quase à hora suprema da separaçāo, de escrever um dia sôbre o homem Euclides da Cunha que se revela tumultuosamente, mas com uma fôrça irreprimivel, em tôdas as suas atividades e reações, como, sobretudo, nas inúmeras cartas aos amigos, deixadas no molde primitivo em que foram lançadas no papel. Nāo era realmente o militar, nem o engenheiro, nem o explorador, mas o escritor que mais vigorosamente traduzia, acentuando-lhe os traços essenciais, o homem admirável que se chamou Euclides. "Oh! que cousa amável o homem quando é verdadeiramente homem!", já exclamava, num de seus mais belos versos, - poeta Menandro. Foi Emerson que disse, porém, nāo ser o homem senāo uma metade; a outra, é a expressāo. Essa segunda parte a que se refere o pai do ensaio, comenta Karl Weissmann, "é, sem dúvida, a parte civilizada de nossa personalidade, nossa cara metade pròpriamente dita. $\mathrm{O}$ mundo humano de filtrados $\mathrm{e}$ depurados reflexos, jamais deixará de figurar como primado da linguagem. Criado pelo Verbo, tende fatalmente a resolver-se em palavras ou em música, seu eqüivalente sublime, apesar de tôda a mecanizaçēo e dos pendores práticos da vida moderna."

Se a linguagem serve ao homem nāo sòmente para exprimir alguma cousa como para se exprimir a si mesmo; se é um dos ins- 
trumentos espirituais que transformam o mundo desordenado das sensações .em um mundo de objetos e de idéias; se ela está diante de nós, "como um teclado verbal", de que se pode arrancar músicas sempre novas, com acentos próprios; se nāo é sòmente uma técnica de comunicaçāo, mas a libertaçāo do homem, reconhecimento e posse de sua alma e de seu ser; se até nos mais escassa e pobremente dotados, como observa Vossler, cintila a chispa'de uma linguagem própria e livre, compreende-se a enorme importância que reveste, para o estudo do homem Euclides, a poderosa linguagem que êle se forjou, para adaptá-la às necessidades de seu espírito e temperamento, à expressāo de suas visões torturadas e de suas terriveis angústias. "Tôda luta, todo o drama, tôda a tragédia dos. sertões encontraram ressonância em sua alma, porque nesta, como pondera Almeida Azevedo, tumultuava em turbilhāo uma tragédia, um drama, uma luta intima, deveras semelhante à da terra brasileira. E quando, pois, nos retratava o sertāo, a perfeiçāo descritiva da paisagem, é menos a fotografia de seu assunto do que o reflexo vigoroso de sua alma" (5). Seja, de fato, em "Os Sertões", em que se revelam, mais do que em qualquer outra obra, os processos habituais do autor, essa maneira a um tempo minuciosa e macissa de análise e expressāo; seja em ensaios luminosos, como "Terra sem história" e "Viaçāo sul-americana", seja numa carta escrita às carreiras, de pé, "de botas, mala a tiracolo e de chapéu à cabeça", é sempre o mesmo escritor a um tempo maleável e robusto, de espírito prodigiosamente lúcido, de sensibilidade excessiva senão mórbida, e imaginação vulcânica, sempre em atividade e pronta para as grandes erupções e descargas emocionais. Nessas belíssimas páginas, e em tantas outras, ricas de substância, de um vigor, de um poder de evocação, de uma faculdade épica e de uma ciência e segurança notáveis, e em que só se apanha o essencial, sem detalhes ociosos, sem imagens parasitas e sem essas repetições em que se acusam tāo freqüentemente as fadigas dos escritores, surge sempre, em corpo inteiro, com seu estilo cintilante, pitoresco e atormentado, o mesmo homem que se move nas alturas, em luta com a própria natureza e a realidade exterior, numa atmosfera saturada de eletricidades. Sua obra, como a definiu Almeida Azevedo, é,-de fato, "todo um jôgo permanente de antiteses, uma sucessão de contrastes, paradoxos e comparações atrevidas, com que êle se compraz", e que the retratam -a capacidade de ver em grande e sua permanente inquietaçāo.

Após os sobressaltos, contorsões e quase violências do estilo de Euclides, em "Os Sertóes", - o seu primeiro livro vingador, para os que buscam a serenidade, só uma digressāo por algumas de suas cartas. O espírito dêsses leitores poderia talvez fazer ne-

(5). - Alyaro Augusto de Almeida Azevedo - Em contato com Euclides, in "O Estado de São Paulo", 15 de agósto de 1946. 
fornecia, como um instrumento de análise e criaçāo; foi nesse convivio com a literatura universal que se lhe desenvolveu o sentido poético e se lhe aguçou êsse espirito de finura que, para o humanismo, vale mais que o da geometria; foi, retemperando-se nessa fonte e colocando-se a essa luz sempre nova que "descobriu, como diria Marrou, as paixões do homem e seu coração profundo e adquiriu assim uma certa experiência psicológica, um sentido afinado dos valores morais, do real e do possivel, do homem e da vida". Em nosso século de inquietaçāo, em que, ao principio do humanismo clássico, isto é, do "homem em primeiro lugar" já ameaçava suceder a aspiraçāo de "a máquina antes de tudo"; nessa dispersāo constante em que se dissipa o melhor de nós mesmos e o nosso tempo se retalha como sob os dentes de uma máquina de picar. teve Euclides o cuidado paciente de cultivar o seu campo, de juntar seus feixes de trigo e de recolher ao celeiro sua farta colheita. Com sua simpatia humana e sua capacidade de admirar, fêz saltar da rocha de uma vida agreste e dura essa provisāo de entusiasmo que lhe permitiu, entre ásperas dificuldades, erigir um monumento cuja maior beleza consiste em refletir a unidade de sua vida profunda, na diversidade extrema das contingencias. Conservou-se sempre êle mesmo através de lutas e provações em que soube manter a elevaçāo de sentimentos, o refrescamento do ideal que os abalos emotivos produzem em nós e, como tinha provisões seguras de inteligência, energia e conhecimentos, poude responder quase sempre com vantagem ao choque das emoções. Indiferente ao ruido e aos sucessos mundanos, sem intriga e sem ambiçóes, ligado ùnicamente a idéias superiores, nāo só enfrentou o temporal que tantas vêzes lhe rugiu às portas da casa e acabou por reduzí-la a ruinas, como sabia arrostar a bonança que, para os navios, como para um homem de seu temperamento, é às vêzes mais perigosa do que a tempestade. Mas Euclides sabia que o homem luta com suas qualidades, quando as tem, mas sobretudo com os seus defeitos; e, tendo-as tantas e em tāo alto grau, os defeitos nāo participavam menos de suas lutas, vitórias e derrotas.

Aliás, os defeitos, que são reações de defesa, entram por igual na composição de tôda personalidade humana, e é sempre dificil traçar entre umas e outras uma linha nitida de demarcaçāo. As fronteiras, pelo geral, são e se mantêm tāo flutuantes que, o que consideramos defeito, pode ser uma alta qualidade, em determinada circunstância, e o que temos por qualidade, em outros casos, se ultrapassa certos limites, já se transforma num defeito. $O$ orgulhoso, o inquieto e o tímido nāo existem senāo como tipos e exemplos; se há pessoas que têm êsses defeitos, ou um ou outro, e em cuja vida êles intervêm, suas próprias atividades e as circunstâncias tāo diversas em que elas se sucedem, modificam também êsses defeitos da mesma maneira que êles se modificam uns aos outros, pelo só fato de sua coexistência. Como ob- 
las, e só em algumas delas, uma cura de repouso. Euclides, como êle mesmo declara, "nāo é homem que se esconda para dizer o que pensa". Mas, se êle sempre esteve só e inteiro em sua obra, no seu destino de artista, - pois que desempenhou uma missāo que só a êle parecia ter sido confiada, - nunca esteve separado, na própria fonte de sua criação, daquilo de que se nutriam espiritualmente todos os que o cercavam e o sustentavam só pelo fato de sua presença. O que mais fortemente lhe repercutiu na obra, não foram, por certo, as idéias, atitudes e tendências das elites burguesas de seu tempo, em cujos quadros abriu uma brecha, com o impeto de uma explosāo, mas a fôrça nativa de seu povo, da gente do interior, e da grandeza desnorteante de seu pais, contraditório e desordenado. Essa comunidade de sentimentos e de idéias, que é condiçāo necessária a tôda obra de arte, necessária, como observa Roger Breuil, a todos os estádios por que passa, - no seu nascimento, porque sua matéria é sorvida no fundo comum da cultura; em sua construçāo, que deve ter um estilo; em sua comunicaçāo, para que seja compreendida; em sua significação, para que possa reagir, modificar e às vêzes, como no seu caso, orientar transformações em curso, - é, com o vigor excepcional com que Euclides se exprimiu, em sua obra, o segrêdo de sua potência irradiadora e de sua fôrça de expansāo. Se nāo há obra de arte digna dêsse nome, senão quando o artista supõe a existência de um fundo comum, - e sendo êsse fundo de que Euclides se alimentou, ainda tāo pouco visivel numa civilizaçāo de litoral, - êsse homen estranho que viveu sua mocidade na capital do país, só podia supôlo por um ato quase desesperado de imaginaçāo. É que, o que nêle, nesse maravilhoso descobridor e pintor de paisagens, naturais e humanas, domina fortemente, prevalecendo sôbre tôdas as outras aptidões, é, por certo, o gênio literário. Espírito realista e romântico a um tempo, que se alia sem esfôrço à franqueza, à objetividade e à fôrça; que modelou, à feição de sua poderosa inteligência, uma linguagem em tudo capaz de exprimir com exatidāo e robustez a realidade de que tomou posse, e de ajudá-lo a senhorear-se das cousas como de si mesmo, escreve, num estilo sacudido e torturado, mas com uma clareza implacável que näo exclui nem o vigor da análise, nem a acuidade de vistas, nem a lucidez das observações, nem a profundeza do pensamento, nem a complexidade, as flutuações e o conflito de sentimentos.

Engenheiro e militar, explorador e cartógrafo, foi nas letras. em contato com a poesia e o drama, o ensaio e a história, que êle encontrou recursos para ultrapassar a profissão e tornar viva a ciếncia que acumulou, trabalhando com o vasto material que the 
serva $\mathrm{Ch}$. Fiessinger, no livro que dedicou ao estudo dos caracteres, retomando a linha dos grandes moralistas do século XVII, entre os dois' centros nervosos que existem em cada um de nós, - cérebro, com sua faculdade de associar idéias, de comparar, julgar e concluir, e o simpático neuro-glandular, com suas impulsões, seus instintos e suas taras, o equilibrio perfeito é uma maravilha muito rara, um estado em que o homem, ainda quando o alcança, tem grande dificuldade em se manter. $O$ que diz Fiessinger, ao analisar, a propósito dos caracteres, a influência dessa fisiologia secreta, nāo é que todos os nossos defeitos nos compõem nossa energia, mas que nós os empregamos, ao menos alguns dêlés, para nos defendermos, e que, depois de os termos utilizado, se tornam habituais e preciosos até nos formarem o caráter. É o que se deu com o nosso grande Euclides. Se êsse equilíbrio instável. entre a sensibilidade e a inteligência, é comum entre os individuos que as nāo têm em alto grau, nāo é de surpreender seja às vêzes tão violentamente rompido em um homem como Euclides, de sensibilidade extrema e poderosa inteligencia, que tinha qualquer cousa de selvagem, e lembra, sob certos aspectos, uma figura escarpada dêsses povos mais próximos da natureza, ainda intactos na sua ganga nativa e com tôda a fôrça e frescura de seus impulsos naturais. Com essa mistura e desordem, em que as rudes imposições da vida intervêm como princípios reguladores, de equilíbrio, soube, porém, Euclides forjar-se uma realidade sintética, ideal, e criar-se, pela constante vigilância sôbre si mesmo, um dêsses sêres de razāo, mais reais, mais necessários e maiores do que o ser acidental de que trazem o nome e que permanece, no entanto, concreto e vivo, em sua obra e em sua conduta, com tôdas as suas singularidades e contradições.

$\mathrm{Na}$ sua personalidade, múltipla e complexa, associam-se, alternam-se ou se chocam a timidez e a impetuosidade, a ternura e a veemência, a humildade e a altivez, e, aos cuidados, incertezas e dúvidas sôbre o próprio valor sucedem-se desabafos de confiança em si e nos outros, como a depressāo ao entusiasmo, as esperanças, aos desfalecimentos. Eleito sócio correspondente do Instituto Histórico, agradece, surprezo, a distinçāo, julgando-a "entre as maiores que podia desejar, tāo falto de méritos se considerava para recebê-la"; fiando-se ainda "muito pouco de seu valor", hesita em aceitar o convite para escrever uma memória sôbre o Duque de Caxias; sobressalta-se, diante de competidores, muito abaixo de seu nivel, à vaga a que se candidatou, na Academia Brasileira de Letras, tendo-se por derrotado, senāo por morta sua candidatura, se o desamparassem os amigos e nāo votassem alguns "imortais", distraidos pelos acontecimentos... Mas êsse homem estranho que, na sua modéstia, se inquieta e se aflige, diante da competição da mediocridade afoita que se acotovela na disputa de cargos, preferências e honrarias; que nunca perdeu, segundo êle mesmo o con- 
fessa, a reserva e a timidez, - "êsse traço de filho da roça que o desequilibra intimamente ao tratar com quem quer que seja", é aquêle mesmo que, aluno da Escola Militar, republicano intransigente, tentou quebrar ao joelho a carabina, e a atirou aos pés de Tomaz Coelho, Ministro da Guerra; o mesmo que, quando tenente, enfrentou Floriano na defesa de seu sogro, o general Solon, e, por näo ter papas na lingua, em relaçāo aos florianistas e ao próprio Floriano, foi transferido para Campanha; o mesmo que, segundo suas palavras, obedecendo ao "belo destino de caçador de perigos. e à eterna ilusāo de ser útil à sua pátria" (6), estava sempre disposto a calçar as botas de sete léguas, para as batalhas obscuras e trágicas com o deserto. Como todos os homens de bem e tôdas as grandes almas, Euclides defende-se menos com os seus defeitos. do que com os seus méritos e virtudes, tomada essa palavra virtude sobretudo no sentido etimológico e o mais verdadeiro que tem em latim o vocábulo virtus, e, em italiano, virtù, especialmente na época da Renascença. Proveniente de vir, homem, como entre nós, virilidade, o poder efetivo e eficaz de um homem, é o total do que êlevale na luta. Salústio nāo apresenta nenhum de seus personagens. sem lhe avaliar a força pela superioridade do que êle tem de energia sôbre o que tem de fraqueza, e aprecia ao justo a virtus de $\mathrm{Ca}$ tilina que é um homem cheio de defeitos, vários dos quais contam na balança de sua virtus e de seu valor individual. Em Euclides, porém, a virtude nāo só exprime a varonilidade, a virtus latina ou a virtú do italiano do Renascimento, mas a virtude, no sentido mais. alto e mais largo, a probidade impecável, o perfeito cavalheirismo e a nobre retidāo.

Já começava Euclides a impressionar pelo aspecto físico, Nāo pela sua estatura, que era baixa, nem por sua constituiçāo, franzina. Mas exatamente por essa energia viril que, no aprumo da atitude e, sobretudo, no olhar e na expressão, já the acusava a "rijidez nativa de caboclo". Eis como o viu Coelho Netto, quando em Campinas, na manhā de $10^{\circ}$ de novembro de 1902 , the apareceu Euclides pela primeira vez, na sala de trabalho, seguido e anunciado desde a porta por César Bierrembach : "Baixei o olhar e dei com um homenzinho secó...; rosto moreno, arestoso como falquejado em vinhático, queixo enérgico, olhar duro, que passava por baixo de meu raio visual e, diante de mim, militarmente apru-

(6). - Francisco Venancio Filho - Enclides da Cunha a seus amigos, v. Cartas a Max 1Fleiuss, 29-5-1903, pg. 97 e 98; a José Veríssimo, 4-7-1903, pg. 102; a Coelho Netto. 10-9-1903. pg. 106; a Lúcio de Mendonça, 1904, pg. 115; e a Fienrique Coelho, 30-7-1906, pg. 179. Companhia Lditora Nacional, São Paulo, 1938. 
mado, como em continência, encarava-me hostil. Pasmei! Que! Pois era'aquilo o titā, o escritor pujante, cujos artigos tanto e tāo alto repercutiam?" $\mathrm{Na}$ sua figura, como no temperamento, áspero e fragueiro, tinha qualquer cousa de selvagem, conforme observou Araripe Junior, um de seus contemporâneos, ou, a regular pelos retratos, de um tipo de asiático, nos seus olhos mongólicos, esgateados. Nāo era de outra maneira que se via Euclides a si mesmo: ao enviar seu retrato a José Veríssimo, pedia-lhe aceitasse, considerando-lhe a boa intençāo, aquêle "desgracioso presente", o "rosto de caboclo", com as "suas linhas desengraçadas", e, em carta a Reynaldo .Porchat, datada de Manáos, lhe declarava que, "firme na sua envergadura esmirrada e seca", fazia, naquele clima canicular, "prodígios de salamandra". Mas, nesse tipo estranho de "caboclo e jagunço manso", como a si mesmo se chamou, eramlhe os olhos e o olhar o que mais feria e retinha a atençāo de todos. "Olhar duro", pareceu a Coelho Netto o olhar com que Euclides o fixou de pé, no seu primeiro encontro com o escritor do "Rei Negro" e de "A Conquista"; olhares "agudos e acesos", que Euclides lançava sôbre todos os objetos, foram os que Araripe Junior pintou, e lhe apareceram poucos dias depois, "no necrotério, apagados, quase estintos, nas crateras das pálpebras arroxeadas" (7). Quando conversava com êle, lembra Gama Rodrigues, (é Alves Motta Sobrinho que nos conta), "seu aspecto mudava, e o que mais impressionava era o brilho e a grandeza dos olhos, negros, luminosos, à flor do rosto, dominando e como que ocupando tôda a sua face magra e triangular, e a maneira estranha e mutável com que nos olhavam. Se falava, sobretudo, se argumentava, eram percucientes e agudos, como que penetrando até o intimo de nossos sentimentos; quando ouvia, eram ausentes e, embora fitando-nos, pareciam mirar outros e mais distantes horizontes, perquirir outros e mais altos assuntos que os decorrentes da conversaçāo. Desconcertante e dominador... completa Gama Rodrigues" (8).

Sob êsse aspecto físico, de homem de estatura meã, mais do que enxuto, descarnado, de olhos vivos e perscrutadores, de movimentos bruscos e atitudes enérgicas, que mais parecia um feixe de nervos, não é difícil descobrir o temperamento de Euclides, instável e impulsivo, cheio de impaciências e de rebeldias. Temperamento singular, como êle mesmo se retrata, "feito para tôdas as dores e para tôdas as alegrias", se se desespera, por nāo encontrar, "no seu tédio lúgubre de Manáos", uma carta de casa, logo se restabelece com a de Coelho Netto, que compara "a uma janela

(7). - Francisco Venancio Filho - Whelides da Cunha a seus amigos, v. Cartas a Coelho Netto, 16-11-1903, pg. 111: a José Verissimo. 1. -10-1903. pg. 110: a Reynaldo Porchat. 18-1-1905. pg. 148; e, no prefácio. pg. 18 e 47, artigo de Coelho Netto, in "Livio de Prata" e "Dois vulcóes extintos", de Araripe Junior. Companhia Editora Nacional, S. Paulo, 1938.

(8). - Alves Mota Bobrinho - Euclides, engenleiro do distrito. Dois anos de permanéncia em Lorena, in "Folha da Manhã", 9 de julho de 1950. 
que de repente se abrisse num quarto de doente"; se, escrevendo do Rio a Alberto Rangel chega a imaginar que, entre tantos concorrentes apadrinhados, poderia ser escolhido para lecionar a história sul-americana, em París, já na carta seguinte, se desculpa de lhe ter falado nessas cousas estranhas, ("Oh! romântico escandaloso e recalcitrante que sou ! exclama Euclides. Felizmente sāo loucuras e absolutamente passageiras"); se, ao chegar a Manáos, sob as primeiras impressões da canícula, investe contra o clima singularíssimo do Amazonas, e o qualificativo, desmoralizado, que lhe deu Bates, "glorious clime", declarando năo poder resistir-lhe senão quem tem "nos músculos a elástica firmeza das fibras dos buritis e, nas artérias, o sangue frio das sucuruiubas", nāo tarda a reconciliar-se com êle, a fazer as pazes com o clima equatorial e a pensar em escrever, para rehabilitar a Amazônia e o clima caluniado, o seu segundo livro vingador, "Um paraiso perdido". Tudo lhe batia nos nervos, os fustigava e os fazia fremir e, sob o impulso das emoções, lá se ficava doente, "a vibrar, a vibrar à-tôa, conforme êle o confessa, como aquelas harpas da gongórica peroraçāo de Mont'Alverne". Alheio e quase hostil às distrações e aos prazeres da vida mundana, só se sentia à vontade, como em seu próprio meio, "buscando a forte distraçāo de seu duelo com o deserto. naquela majestosa arena de quinhentas léguas que lhe oferecia o Purús", e com tôdas essas tempestades, quase desejadas, da alma e da vida, o Sturm und Drang das belas barbarias. Sua imaginaçāo e sua impaciência, agitando tudo, revolvendo tudo, ativando tudo, nāo procedem nem sāo bem sucedidas senāo por impulsos; e, por mais que se esforce em lhes dar uma impulsāo única e retilinea, êle permanece, apesar de seu espirito realista (que homem complexo e contraditório!), um imaginativo fogoso, um sonhador do grande: transborda de si mesmo e não se possui todo inteiro. Como todo grande homem, tem alguma cousa de desmesurado e excessivo, e em nada se parece com o gênio ocidental que, considerado nas suas mais nobres criações, comporta sempre não sei que de medido, de temperado e de equilibrado. Gênio da raça, a um tempo mítico e real, Euclides, como êle mesmo se reconheceu, foi "um ser enigmático, verdadeiramente incompreensivel entre os seus contemporâneos" (9).

A nervosidade excessiva, a extrema susceptibilidade e, em conseqüência, a facilidade de responder pronta e quase sempre

(9). - Francisco Venancio Filho - ibidem. Cartas, a Coelho Netto, 10-3-1905. pg. 152; a Alberto Rangel, 20-9-1908, pg. 216 e 24-10-1.908, pg. 220; a Joŝ Veríssimo, 13-1-1905, pg. J45 e 146, e 2-2-1905, pg. 152; a Coelho Netto, 10-9-1903, pg. 1.07; a Afonso Arinos, dezembro de 1904. pg. 143 ; e a Francisco isscobar, 13-6-1906, pg. 176. 
desmedidamente aos menores estímulos provenientes quer dos homens e da vida quer da natureza, se estavam ligadas ao temperamento constitucional, agravavam-se pelo seu estado de saúde e com as constantes fadigas e atribulações. Era um homem sempre às voltas com problemas e preocupações de tôda ordem, a que a sensibilidade e a imaginaçăo como sua crônica dispepsia emprestavam geralmente proporções exageradas. Os dispépticos serāo pobres criaturas? Não vos apresseis em lastimá-los. Eles têm compensações e desforras : uma sensibilidade muito fina, a intuiçāo aguda, a inteligência inquieta e uma feliz disposiçăo a se irritarem que cria a docilidade à volta dêles... É o próprio Euclides que se refere ao seu "ursismo", à sua "virtude ferocíssima de monge e de dispéptico". Mas, que assombrosa energia moral a que se acumulou nesse homem atormentado, em que as moléstias vinham e se iam, apesar de sua "organizaçāo de salamandra", nāo se atrevendo a instalar-se naquele organismo que parecia extrair fôrça de suas próprias fraquezas. Todos sabemos os perigos e as dificuldades tremendas que reserva aos exploradores a zona equatorial, sob as formas as mais pérfidas e insidiosas. Pois, Euclides, quando em 1905 se preparava, em Manáos, para a expediçāo ao Alto Purús, nāo hesitara um momento diante da emprêsa temerária, ansioso por partir, "firme na convicçāo de dominar as cabeceiras do grande rio"; e "como, acrescenta êle, nāo creio que os hematozoários e filárias cobicem a minha organização estéril e sêca, o triunfo será inevitável". Do Rio, escreve em 1908 ao poeta Vicente de Carvalho, no mesmo tom : "continuo meio adoentado, mas nāo creio que as moléstias vinguem na aridez maninha dêste meu organismo asperamente sêco, donde o próprio beriberi acreano já fugiu espavorido (sem remédio) para nunca mais voltar". Graças aos deuses (desabafa-se com Firmo Dutra), "aqui, no Rio, estou armado da minha bela energia de caboclo e enfrentando a rir os trambolhões da vida que afinal são menores que as 73 corredeiras do Cujar" (10). Sob a pressāo dêsse temperamento tempestuoso e aos impulsos dessa vitalidade transbordante, êle procede sempre com hesitações e temeridades, passando da indecisāo, da inquietude < da dúvida até à angústia, à resoluçāo corajosa e às decisões supremas tomadas quase como uma violência contra si mesmo, mas impelidas sempre pelo sentimento do dever, por êsse amor, digno e altivo, justo, cujo ideal se forma tanto com os gritos dos oprimidos quanto com o enternecimento dos profetas, êsse amor à honra e ao ideal, - o único viril, desconhecido e menosprezado nos períodos de decadência.

Este homem desabusado, mas irresoluto ("Como sabe, eu sou de uma irresoluçāo vergonhosa", escrevia êle ao seu sogro, general

(10). - Francisco Venancio Filho - ibidem. Cartas a Coelho Netto, 7-8-1904. pg. 129; a Domficio da. Gama, 17-3-1905, pg. 157; a vicente de Carvalho, 4-12-1908, pg. 225; a Firmo Dutra, 25-3-106, pg. 172. 
Solon), extremamente sensivel às irradiações do mundo exterior como às vibrações do seu mundo interior, mantinha-se em guarda e numa luta permanente contra o seu temperamento e possuia um poder notável de limitação e de dominação sôbre os apetites e os instintos, as impulsões e as repulsões. Entre tantos elementos múltiplos e contraditórios, na realidade ou na aparência, de que resultava a sua fragosa personalidade, pôde cimentar uma admirável unidade moral, que se lhe impunha à consciência com uma fôrça irresistivel. Apesar de uma mocidade revolucionária era, como êle o admitia, um timido, a quem assustava "qualquer conceito dúbio ou vacilante"; e, já homem célebre, no primeiro encontro com o Barāo do Rio Branco, segundo o testemunho de Domício da Gama, conversava "respeitoso, comovido, e tímido, como um estudante à hora de exame", sôbre questões, em que era mestre, de fronteiras e relações internacionais. Agradava-lhe, sem dúvida, o isolamento que é (sāo palavras de Euclides), "como o do poraquê cheio de descargas entre os moluscos amazônicos", e se tornou quase uma necessidade no curso de sua vida, severa a ascética, em que se sentia cada vez mais solitário, "no meio de uns sujeitos nos quais pouco mais distinguia do que os acidentes geométricos e mecânicos de formas em movimento"... Altivez e êsse orgulho legitimo que provinha da justa consciência de seu valor, antes subestimado, nas suas dúvidas e inquietações, quem poderia deixar de lhe reconhecer? Quando pensou certo dia num passeio, nāo a Paris .(observai-o bem) mas ao Acre, nāo tardou a cair em si, reconhecendo com mágoa as dificuldades de realizá-lo, nesta terra, "onde (escreve êle) para tudo faz mister o pedido e o empênho, duas cousas que me repugnam. Eliminei, por isto, a aspiraçāo". Com tanta ufania quanta verdade pôde êle proclamar que "venceu por si só, sem reclames, sem patronos, sem a rua do Ouvidor e sem rodas" (11). Era tímido e arisco? Amava a solidāo? Retraia-se de nojo ou revolta diante da mediocridade triunfante? Nāo rastejava em face de poderosos? Mas a timidez, o gôsto da solidāo, o orgulho que constituem o séquito normal de temperamentos como o seu, e naturais reações de defesa, se eram defeitos, nunca dêles se utilizou Euclides como armas ou estratagemas contra vizinhos ou inimigos. Profundamente sincero e leal, - sinceridade rude e quase feroz, lealdade a tôda prova, - seu afastamento do mundo, seu ar imperioso e desconfiado, sua maneira nervosa de escrever, como de discutir, sua irritaçāo mal dissimulada contra tudo o que era frívolo e banal, seu horror à mediocridade e ao ridículo, à hipocrisia e à lisonja, refletiam-lhe a tempera de aço e lhe davam uns ares nos'tálgicos de gigante que se sentisse exilado entre os homens e só à vontade, nas lutas ásperas com as selvas e o deserto.

(11). - Cartas. ao General Solon.-10-1-1897; a Jülio Mesquita (sem data): a Oliveira Lima, 13-11-190S: ao Dr. Luiz Cruls, 20-2-1903; a seu pai, 25$-2-1903$, in Euclides da Cunha a seus amigos, pgs. 62, 55, 223, 84 e 85 . 
Tudo o que lhe deparava aos olhos o espetáculo.desolador da cidade, com o seu ambiente corrupto e corruptor, com a trama vil de suas intrigas e as brutalidades das competições sem freios, com sua récua de desfibrados e mediocres e a legiāo inumerável de espertos e malandros felizes acotovelando-se por tôda a parte, sacudialhe e irritava-lhe os nervos e o fazia descambar a todo o momento para êsse pessimismo que êle mesmo qualificava de "desalentado", de "abominável" ou de "incurável", e se exprimia em confidências amargas e desabafos desesperados. Anseia por encontrar-se com Escobar "para remascar velhas frases e um velho pessimismo, para escalpelar algumas dúzias de politicões, dando largo curso (lembra Euclides) à nossa bilis vingadora de revolucionários"; e. escrevendo a Domicio da Gama que se achava embaixador em Lima, quando percebe que vai rolar por êsse declive de tristezas e desalentos, se detém "para nāo atirar de longe os respingos amargos de seu pessimismo e dessa melancolia irremediável". Tinha em alto grau o sentimento da gravidade e da seriedade da vida que levava até o trágico, reagindo contra a melancolia, contra a sua "tristeza congenial, de bugre", com as suas investidas sarcásticas e as suas violências vingadoras. Nesse revolucionário avant la lettre, nesse avant-coutrier, pioneiro que via longe e profundamente, o seu pessimismo nāo era, porém, daqueles que costumam desenvolver-se nos periodos de decadência ou nas grandes crises sociais em que se geram ou florescem as doutrinas pessimistas, mas estava antes ligado a essa insatisfaçāo de necessidades, de desejos, de aspirações $e$ de ideal que implicam o próprio progresso e a crença no progresso, de um lado, e, de outro, as oposições e dificuldades que se levantavam, por tôda a parte, aos seus ideais e impulsos de renovaçāo. Se o temperamento, as suas inquietações interiores e uma vida torturada, sem estabilidade e segurança, constituiam um campo de cultura favorável à eclosāo dêsse pessimismo atroz, a desenvoltura da mediocridade, audaciosa e premiada, o espetáculo da subserviência e da bajulaçāo e o desinterêsse geral pelos problemas fundamentais do pais contribuiam para exacerbá-lo, cerrando-lhe os' olhos aos aspectos amáveis da vida. Preferia manter-se ao lado da exigua minoria dos que entendiam, já na sua época, que "o melhor serviço a prestar-se nesta terra consiste sobretudo na seriedade, que é uma forma superior de heroismo no meio dêsse enorme desabamento..." Nem no contato com a mocidade de seu tempo, despreocupada e frivola, encontrava, no seu idealismo sem fadigas, um meio de cura do pessimismo avassalador que the devorava as energias. Desencantado da mocidade, hesitava, ao escrever a Coetho Netto que lhe participava o nascimento do seu $12 .^{\circ}$ filho, em lhe dar parabens, por "êsse transbordamento de vida" : para êle, uns restos de mocidade nacional (sāo palavras suas, tristes e desoladas) ainda estavam nas almas de meia dúzia de sexagenários dos bons tempos de outrora. Entre êsses desfibrados e jovens im- 
becis (acrescentava Euclides, em um de seus momentos mais amargos) tenho às vêzes vontade de perguntar a um Andrade Figueira, a um Lafayette e a um Ouro Preto se já fizeram vinte anos" (12).

Poder-se-ia julgar que, num homem dessa fibra, de caráter altivo e bravio, roido de tristeza e pessimismo, com uma visāo severa e quase trágica da vida, ou nunca existiu ou se teria secado a fonte de piedade e de ternura humana. Pois, nada menos verdadeiro. Não é preciso lembrar, para se avaliar tôda a falsidade contida nessa suposiç⿳亠丷厂, a palavra de Nietzsche: "grandes desprezadores, grandes adoradores..." As atitudes e os gestos, sua vida intima, suas relações de amizade e a vasta correspondência que deixou, estāo aí para testemunhar os tesouros de afetividade que guardava aquêle grande coraçāo. Os cuidados e desvelos de pai manifestam-se a cada momento em suas cartas, como se pode observar quando, de volta a Lorena, encontra seu filho queimado, o rosto em chaga, vitimado por uma bomba; escreve então a Francisco Escobar, às pressas : "Imagina lá o meu espanto e a minha dor..." Nào sou mais extenso porque tenho de atender a todo instante ao doentinho que exige agora tôda a nossa atençāo". De Manáos, onde ia sempre ao correio para assistir à abertura da mala postal, "com a preocupaçāo absorvente de encontrar cartas de casa", que nāo recebia havia dois mêses, pede a Coelho Netto nāo se esquecer de visitar, com a senhora, as suas "quatro enormes saudades", na sua fazendinha de Laranjeiras, no Cosme Velho. E o que também roga, ansioso, a José Verissimo e a sua senhora, - "que visitem sempre (escreve Euclides) as minhas quatro imensas saudades, no retiro das Laranjeiras, onde passo idealmente o melhor do meu tempo". Ainda de Manáos, já agora a Alberto Rangel : "Um favor, mas favor sacratíssimo de irmāo. $\mathrm{Na}$ rua Cosme Velho, 91 (atual rua de Francisco Otaviano) moram as minhas quatro grandes saudades, a minha mulher e os meus três pequenos. Peço-te que os procures e lhes dê noticias minhas". Aos filhos, como se vê, e à mulher nāo se refere senāo chamandothes "as minhas quatro grandes", "as minhas quatro imensas" ou "as minhas quatro grandes e permanentes saudades". Sòmente quando the bateu à porta e em sua casa se projetou, como uma sombra sinistra, a terrivel desconfianca, deixa escapar êste desabafo doloroso, em carta a Francisco Escobar : "também por aqui

(12). - In Euclides da Cunha a seus amigos. Cartas, a. Francisco Escobar. 26-12-1906. pg. 18:5: a Tosf Veríssimo. 10-3-1005, pg. 150: a Francisco Escobar, 13-6-1906, pg. 174; a Domf́cio da Gama. 15-8-1007. pg. 190, e 16$-11-1907$, pg. 194; a José Verissimo, 6-9-1904, pg. 133; a Coelho Netto, 10-3-1905. pg. 154 . 
me anda a praga dos filhos. Nasceu mais um no dia 16 de novembro. Chamei-o Luiz, percorrendo o calendário exausto". Mas êsse homem, ríspido e destemeroso, sobranceiro a perigos, que vivia com a palavra "saudade" na pena e nos lábios, porque ela se aninhava no coraçāo, assustava-se diante dos impetos de sua própria ternura. "Tenho medo da sáudade... (escrevia de Manáos a Porchat) temo que ela se expanda livremente em quatro páginas. E o que mais me dói nesta vida aventureira : as imagens dos amigos constantemente evocadas e cada vez mais impressionadoras à medida que se aumentam as distâncias" (13).

Amigo, Euclides da Cunha? Amigos de Euclides? Pois não. Ninguém o foi com mais fidelidade e mais calor; ninguém lhe levou vantagem na capacidade de atrai-los, conquistá-los e prendê-los. "Meiga e profunda afetividade", era a de Euclides, no depoimento de Afrânio Peixoto; "amigo boníssimo", chamou-lhe Firmo Dutra; "amigo tāo seguro e de trato tāo suave, na sua singeleza afetuosa", observa, de sua parte, Domício da Gama; "é agreste, reconhecia. Coelho Netto, fruto selvagem, de aparência hispida; descascado, porém, no âmago é um favo". É que Euclides que tinha o culto da amizade, colocava acima de tudo, de suas pretenções mais caras e de suas ambições mais legitimas, a dádiva preciosa de um coraçāo aberto. Abençoa o insucesso de sua pretensāo a um cargo de lente substituto na Escola Politécnica de S. Paulo : que importa, se fôra "largamente compensado"? Mas, como? "Procurava ansiosamente (escreve a Henrique Coelho) uma cadeira, uma prosaica posição de lente, - e encontrei dois corações. Felizmente, prefiro os últimos. Sou um eterno idealista" (14). Êle tinha sêde de ternura. Era um embriagado, nāo do amor, mas da amirade, na sua concepçāo antiga. Cartas de amor, nāo as escreveu, que se saiba; nāo se the conhecem aventuras amorosas, nem na longa e mais intima correspondencia que manteve, se encontra $>$ mais vaga e discreta alusão a qualquer interêsse feminino, de uma vida aventureira e aventurosa. Seria inútil procurar mulheres. ımigas ou inspiradoras, na vida de Euclides. A essência de sua dmizade, temperada ao gôsto helênico, era antes de tudo, para empregar palavras de Marrou, referindo-se à Grécia clássica, "uma certa forma de sensibilidade, de sentimentalidade, um ideal misógino de virilidade total", uma comunhāo mais estreita do que a que liga irmāos ou os pais aos filhos. Seus amigos (e êle os teve numerosos, solícitos e dedicados) chamavam-se, entre tantos outros, Francisco Escobar, Júlio de Mesquita, Reynaldo Porchat,

(13). - In vuclides da Cunha a seus amigos. Cartas, a Francisco Escobar, 14-5-1909. pg. 72; a Coelho Netto, 10-3-1905, pg. 154: a. Tosé Verissimo. 19-3-1905, pg. 161-162; a Alberto Rangel, 20-3-1905. pg. J64; a Iscobar, 28-11-1907, pg. 198. a Reynaldo Porchat, 18-1-1905. pg. 148.

(14). - In Euelides da Cunha a seus amigos, pg. 9. 39. 32 e 20; Carta a Henrique Coelho. $9-9-1.904, \mathrm{pg}$. 137 . 
Vicente de Carvalho, Firmo Dutra, Alberto Rangel, Oliveira Lima, José Veríssimo, Coelho Netto... Tão sensivel ao encanto dos céticos, indulgentes e irônicos, como Machado de Assis, quanto ao sôpro de inspiraçāo lírica de um Vicente de Carvalho, ou à influência intelectual e moral, "à estranha e majestosa gentileza", de um Barāo do Rio Branco, que "nāo havia meio de poder êle considerar sem as proporções anormais de um homem superior à sua época", Euclides dava-se a todos com essa aceitação e tolerância que não eram qualidades suas, mas se alimentavam da admiração e do culto da inteligência como do foco interior em que tomava consciência das afinidades eletivas. Gostava, por isto, de substituir a frieza e a troca protocolar por êsses contatos de homem a homem, essas conversações espontâneas, de viva voz ou à distância, em que nada se pudesse ocultar a outrém, essas efusões depois das quais nāo fôsse possivel duvidar nem de sua nobreza de alma nem de sua sinceridade radical. Ardente e apaixonado, bom escutador e conversador discreto, mas capaz de se empolgar, estava sinceramente convencido de que nenhum gêlo se manteria diante de tanto calor concentrado e de que as questões e dificuldades mais vivas lhe fariam o prazer de se aplainar diante da forç̧a com que, na intimidade, se lhe expandia o coraçāo.

Nāo é, pois, de estranhar que nenhum dos que procuraram fazer-se uma idéia ou traçar o perfil dêsse homem extraordinário, duvidou da pouca seqüência, direi mesmo do tumulto que reinava nesse espírito, do desequilibrio entre a imaginaçāo e a realidade, das alternativas de doçuras e revoltas, de encantamentos e repulsas, de ilusões e desilusões. Mas, se nesse homem feito de singularidades e contrastes, alguma cousa tomou ao bronze o som, a perenidade e a solidez, foi o seu caráter rigido e austero, temperado nas lutas consigo mesmo e com o mundo exterior, sob a inspiraçāo de uma alta concepção de vida moral. O traço mais saliente de seu caráter era a altivez, susceptivel e indomável, em que êle via o privilégio de sua superioridade, e que montava guarda, como uma sentinela vigilante, ao seu sentimento cavalheiresco do dever e da honra. Reagia imediata e violentamente contra atitude, gesto ou palavra, nāo digo que o atingisse mas que êle tivesse a suspeita de que poderia tocar de leve a sua dignidade pessoal. Na hierarquia de valores que lhe constituiam a concepçāo de vida, preponderavam, sôbre todos, os valores morais. O que procurava sobressaltar em si mesmo, e mais respeitava nos outros, era o homem. Este, o primeiro aspecto humanistico, do homem que foi Euclides da Cunha. Escrevendo de Lorena ao pai, a quem dava notícias de sua eleição para a Academia Brasileira, com os votos de figuras eminentes como 
Machado de Assis e Rio Branco, concluia : "Mas nāo tenho vaidades : tudo isto me revela a bôa linha reta que o snr. me ensinou desde pequeno. Hei de continuar nela". Confessa, em outra carta, ter sido idealista de mais e, arrependido, promete ao pai "fazer o possivel para considerar as cousas pràticamente, sem contudo.perder (acrescenta) a minha velha linha reta à qual já estou habituado". Êsse caboclo, de julgamentos severos, que nāo tinha vaidades e raramente se referia a seus livros, que vivia sobressaltado de dúvidas a respeito do próprio valor e se inquietava com as criticas ao que êle chamava "os pecados originais de minha maneira de escrever", se de alguma cousa se orgulhava, nāo sem certa candura, era de sua "alma aqüilina e santa", do "vigor de sua belíssima alma sonhadora", .como êle se reconhecia com palavras que já não the pareciam vitupério na própria bôca, quando aludia ao seu caráter e à sua vida moral. "Nāo tinha rancores, como se fôsse superior ao ódio (testemunha Domício da Gama), e essa serenidade de sentimento, purificado pelo entendimento que nāo reconhece culpas e, em tudo, só enxerga relações entre causas e efeitos, contrastava com a veemência febril e trepidante de suas admirações. É assim (conclui Domício) a psicologia dos santos: adorando o bem, ignorando o mal" (15).

Mas, se tendes por parciais ou generosas as palavras dos amigos e, por suspeitas as de Euclides, nos seus próprios desabafos confidenciais, não faltarāo, para demonstrá-lo, grandes e pequenos fatos da mais profunda significaçāo. Nunca vacilou no cumprimento dos deveres para consigo e para com os outros. Quando Floriano mandou prender o General Solon e se propagou a noticia de que êsse militar seria fuzilado, nāo hesitou Euclides em acudir ao sogro : dirigiu-se ao Itamarati para interpelar o Marechal de Ferro, e, falando-lhe desassombradamente, sem deixar de lhe declarar que nāo o acompanhava como homem nem era seu partidário, embora o seguisse, porque defendia, como êle próprio, a República, obteve de Floriano as palavras tranqüilizadoras. Não pesava sôbre o sogro a terrivel ameaça. Quereis agora uma prova de seu vivissimo sentimento de honra? E ler a carta que escreveu ao General Solon, seu sogro e um dos fundadores da República, quando se anunciou sua transferência como um castigo, para Mato Grosso. É uma página forte de uma nobreza incomparável. "A situaçāo de nosso país é grave (escreve entāo o tenente Euclides): eu sou dos que entendem que nós devemos todos formar ao lado do govêrno atual, - isto, porém, nāo nos pode obrigar a fugirmos das imposições nobilitadoras da honra... Se nāo pedistes tal transferência, não a aceiteis. Há cousa que, para nossa familia e a nossa pátria, vale

(15), - In Euclides da Cunha a seus amigos. Cartas, a seu pai. 22-9-1903, pg. 107, e 25-8-1904, pg.. 131; a Coelho Netto, 22-11-1903, pg. 112; Domício da Gama sobre Ituclides, ibidem, pg. 32 . 
mais do que a espada de general, é o vosso caráter de homem". Reparai ainda a atitude de protesto que assumiu, contra o senador pelo Ceará, Joāo Cordeiro, quando êste sugeriu se lançassem sôbre os rebeldes, recolhidos às prisões, as mesmas armas criminosas empregadas pelos que tentaram dinamitar o jornal "O Tempo". Embora solidário com o govêrno na repressão dêsses atentados, surge pela imprensa, indignado, contra "o alvitre singular e bárbaro, que deve cair de pronto (são palavras suas), sob a revolta imediata dos caracteres que, na época dolorosa que atravessamos, tenham ainda o heroismo da honestidade". Quereis, porém, um atestado de sua heroicidade e estoicismo na luta, da delicadeza de seus escrúpulos e de seu desprendimento pessoal sem limites? Convidado, em 1893. pelo Marechal Floriano para uma entrevista, Euclides comparece à presença "do grande doador de posições" que, referindo-se à sua recente formatura e ao seu entusiasmo pela República, lhe declarou que, "tendo éle direito a escolher por êle mesmo uma posiçāo, nāo se julgava o Marechal competente para indicá-la"... Diante dessa perspectiva, e no momento "em que estavam no pleno despencar dos governadores estaduais", que pede Euclides a quem tudo the podia dar? O govêrno de um Estado? Nāo. Declarou-lhe ingenuamente "que desejava o que previa a lei para os engenheiros recém-formados : um ano de prática na Estrada de Ferro Central do Brasil!"' (16).

E que êsse "caboclo malcriado e teimoso no seguir a linha reta no meio das contorsões e tortuosidades que o rodeiam" (são palavras suas), era, sobretudo, um romântico, - "romântico escandaloso e recalcitrante", como êle mesmo se definiu, "romântico incorrigivel", que nāo hesitou em dar plena razāo a Joāo do Rio, quando na "Gazeta" o proclamou "o único funcionário público romântico que ainda houve nesta terra", e que reivindicava para si "o belo titulo de o último dos românticos". Era assim, desde criança, um deslumbrado diante de tudo. Extasiado ou revoltado, sempre disposto, por uma espécie de megalopia, a ver tudo em grande e a dar proporções desmedidas às suas admirações e às suas revoltas. $\mathrm{Da}$ pequena e encantadora Nova Friburgo, - a primeira cidade que viu "na mais remota juventude", o que the ficou e conservou" neste rever na idade viril", foi (diz êle) "uma impressão de criança, a imagem desmesurada de uma quase Babilônia"... Nāo viu de outra maneira a cidade de Belém do Pará que visitou, já aos 38

\footnotetext{
(16). - In Euclides da Cunha a seus amigos. Cartas. ao General Solon, 6-1-1894, pg. 61; a Ganeta de Noticias, 18-2-1894, pg. 57; a Júcio de Mendonca, 1904, pg. 114.
} 
anos, em plena maturidade, e foi, segundo confessa, "a maior sur. preza de tôda a viagem", com as suas avenidas monumentais, "com os seus edifícios desmesurados, as suas praças incomparáveis e com a sua gente de hábitos europeus, cavalheira e generosa". O Rio de Janeiro, quando apenas começava a despojar-se de sua vestitura colonial para se transformar, com Pereira Passos, numa metrópole moderna, como a viu Euclides? "A vida entre nós, mudou, escreve a Domício da Gama. Há um delírio de automóveis (isto, em 1907!), de carros, de corsos, de recepções, de conferências, que me perturba e me atrapalha, no meu ursismo incurável. Dá vontade da gente representar a ridicula comédia de Catāo, saindo por essas ruas, de sapatos rotos, camisa em fiapos e cabelos despenteados. Que saudades da antiga simplicidade brasileira".. Como julga o seu "Perú versus Bolivia", em que reuniu os artigos publicados no "Jornal do Comércio" e inspirados no culto da verdade e do direito? "E uma das minhas quichotadas. Constituiu-me, por satisfazer à indole romântica, um cavalheiro andante da Bolivia". Êle o reconhece e muitas vêzes o proclamou : "Sou um maravilhado diante de tudo (disse o Verissimo ùltimamente) e a minha admiraçāo "nāo raro ultrapassa a realidade". A idealizaçāo (acrescenta êle numa carta a Francisco Escobar) submeto-a aos estudos mais positivos, envolvo-a no cilício dos algarismos, esmago-a ao pêso das indagações mais objetivas, - e ela revive-me cada vez maior, e triunfante. Mas, nessa quadra de "grandes nivelamentos", talvez tenha realmente uma função primordial o aprumo de uma inteligência rebelde e sonhadora" (17).

Mas o que é verdadeiramente notável (e aí está o segundo aspecto do humanismo de Euclides) é que, sendo um romântico quase visionário, de imaginaçāo fogosa e às vêzes delirante, haja conseguido por uma disciplina ascética, reprimi-la e domesticá-la, submetendo-a, tanto quanto lhe era possivel, às exigências do espirito positivo. Escritor, poderoso escritor, que, sob a influência do naturalismo e do espirito critico, nos deu "Os Sertóes", - essa grande obra, em que confinamos com o romance sem deixar a realidade, apanhada com uma lucidez espantosa, constrói epopéias, com imagens magnificas, sinteses e audácias de côres, uma riqueza de idéias e de palavras, uma ciência de processos, em que se resume a um tempo, com a observação metódica de um pesquisador, todo um romantismo numa suprema e borbulhante floraçāo. Historiador, destacou-se da fantasia, desertou do reino dos sonhos, para pensar e escrever a respeito da vida e da história do povo, em "À margem da história", páginas de primeira ordem, como "Um

(17). - In Euclides da Cunha a seus amigos. Cartas, a Otaviano Vieira. 5-11-1908, pg. 220, a Francisco Escobar, 28-11-1907. pg. 198; a Machado de Assis, 15-2-1904, pg. 116; a seu pai, 30-12-1904, pg. 141; a Domício da Gama. 16-11-1907. pg. 196, e 15-8-1907. pg. 191; a Francisco Escobar, 10-4-1908, pg. 206, 
século de Independência", construidas sôbre peças cuidadosamente cbservadas. Cartógrafo e auxiliar técnico, que o Barāo do Rio Branco reteve no Ministério, em seu gabinete, terminada a missāo no alto. Purús, transformou-se, de escritor impetuoso e ardente, num técnico notável, que, no testemunho de Domício da Gama, pôs a serviço do país, em anos de trabalho escrupuloso, a sua erudição histórica, o poder e a argúcia de sua dialética, e a sua capacidade beneditina de pesquisa em arquivos e de interpretaçāo de mapas e documentos antigos. Explorador que se arriscava em.excursões perigosas e rompera quinhentas léguas de desertos, ninguém podia imaginar o chefe intrépido, empreendedor e tenaz em que se transmudou o incorrigivel romântico, admirável já na coragem e na ordem calculada com que prosseguia, através de imensas dificuldades, em suas missões distantes, já no cuidado extremo no coligir os resultados mais particularmente cientificos de seus empreendimentos. Certamente êsse esfôrço para o dominio da imaginaçāo rebelde, essa vontade obstinada de submissāo ao objeto, nem sempre tentada com êxito, essa procura insatisfeita da verdade e dos fatos, pelas especulações teóricas como pela investigação metódica, tinham, para apoiá-las, nāo só a disciplina da cultura matemática, como também o cultivo das ciéncias, - da geografia e da geologia, da antropologia e da sociologia, de que apreendeu, num convivio diuturno mas de forma assistemática, o espirito e os métodos positivos. Sensivel, como um romântico e realista a um tempo, a êsse maravilhoso cientifico que nada tem de sobrenatural e se apresenta como uma conquista do homem sôbre a natureza, Euclides amava as ciências tanto por suas aplicações quanto pela beleza e harmonia de suas construções teóricas, e, se em nenhuma delas chegou a especializarse, delas nutriu suas obras e se utilizou sempre, como de um instrumento de análise, para aguçar aquêle olhar extraordinário que é o de todos os que revolucionaram a literatura, as artes e as ciências.

Pode-se legitimamente amar a ciência "por suas aplicaçôes, escreveu Louis de Broglie, pelos alivios e comodidades que ela trouxe à vida humana, sem esquecer todavia que a vida humana ficará sempre, pela sua própria natureza, precária e miserável. Mas podese, pensamos nós, achar uma outra razão de amar o esfôrço científico, apreciando o valor do que êle representa. Com efeito, como tôdas as grandes cousas, é sôbre o plano espiritual que êsse esfôrço adquire plenamente o seu valor : é preciso amar a ciência porque ela é uma grande obra do espírito". Foi como Euclides a amou, pelo seu valor social e pela sua utilidade, por ser uma das maiores conquistas do espirito humano e representar o domínio das fôrças naturais pelo homem, mas sem dogmatismos e sem exclusivismos e, 
sobretudo, sem separar, na sua dilecçāo, o culto das letras' e o das ciên,cias, como no grande século dos belos espíritos que nāo distinguiam umas e outras, nas suas aspirações. E êste, a meu ver, o terceiro aspecto do humanismo de Euclides, marcado por sua concepçāo do homem total, do homem em si, do homem completo e por seu interêsse vivo, e por vêzes angustiante, por todos os problemas do espírito e do coração humano. Rebatendo críticas de José Verissimo ao emprêgo, talvez excessivo, de têrmos técnicos que certamente nāo empanam o brilho da beleza macissa de "Os Sertöes", reprova Euclides o sistemático desprêzo que lhes votam os homens de letras, sobretudo se considerarmos (acrescenta) que "o consórcio da ciência e da arte, sob qualquer de seus aspectos, é hoje a tendência mais elevada do pensamento humano". Em Guarujá, aonde o conduziu a profissāo, na sua vida rude de caixeiroviajante da "engenharia a retalho", passa, como escreve a Coelho Netto, "o melhor das vidas às voltas com o gárrulo $H$. Heine ou com o Gumplowicz terrivelmente sorumbático". Escrevendo a Vicente de Carvalho que lhe pedira um prefácio para o livro "Poemas e Canções", lamenta nāo ter consigo "as melhores páginas de sua livraria errante, desde Shakespeare a Antero de Quental. Ao meu lado, (conclui com amargura) enquanto nāo se fixar a minha posiçāo no planeta, apenas os estúpidos livros profissionais". No entanto, para se afeiçoar ao extraordinário idealismo do poeta de "Rosa de amor", lá se fica êle lendo Emerson: "É um training do espirito, observa Euclides com êsse ceticismo científico que tem a sua razāo de ser. Para desemperrar-me, o trapézio maravilhoso do maior dos metafísicos da arte. Sòmente assim me libertarei por algum tempo da miserável ilusāo científica, onde a hipocrisia da verdade se mascara de fórmulas presumptuosas e traiçoeiras" (18).

Inquieto e torturado pela dúvida, sempre incitado para o alto, mas sem se decidir por qualquer sistema ou doutrina na interpretaçāo da vida e da realidade objetiva, Euclides, por temperamento e formaçāo, era o tipo do homem incapaz de se encerrar numa cultura particular e para o qual nāo havia caminhos com o sinal fechado. Engenheiro e técnico notável, a sua curiosidade pelas letras, como pelas ciências, tanto pela história quanto pelas artes, levou muitos, por isso, a considerá-lo, não sem certo desprêzo, como êle mesmo se queixava, "um engenheiro letrado", antes da publicaçāo de "Os Sertões", e, depois, "um escritor desgarrado na engenharia"... Essa engenharia "fatigada e errante", de que tantas vêzes se lamentou, nāo lhe parecia, na realidade, senāo "um desvio morto de que esperava sair sem descarrilhar, (sāo palavras suas) aproveitando o primeiro triângulo de reversāo que apareces-

(18). - In Fuclides da Cunha a seus amigos. Cartas, a José Veríssimo, 3-12-1902 , pg. 80 ; a Coelho Netto, 7-8-1904, pg. 130; a Vicente de Carvalho. 18-0-1908, pg. 214-215. 
se, para avançar na sua verdadeira estrada". - a estrada, larga e humana, de seu alto ideal de cultura. Com essa permanente inquietação de espírito, com essa curiosidade universal por todos os problemas humanos, nāo podia o engenheiro Euclides da Cunha manter-se, como nāo se manteve, estranho ao próprio problema religioso, mais do que todos assoberbador, que de vez em quando o agitava, atirando-lhe perguntas que nāo ficavam sem respostas. Se, em conversa à distância com Alberto Rangel, fala em sua "incorrigivel impiedade" e lhe declara que, apesar disso, "só o pecado de lhe invejar a felicidade de filho, bastaria para que the abrissem todos os céus (se os céus existissem)", é para confessar depois a Otaviano Vieira, seu cunhado, que os contrastes da vida o estavam tornando espiritualista e que "por fôrça deve haver um au-delà onde se corrijam tantos absurdos e tanta miséria"... "Entāo... eu nāo creio em Deus?! responde êle a Coelho Netto. Quem te disse isto? Puzeste-me na mesma roda dos singulares infelizes que usam do ateismo, como usam de gravatas, por elegância, e por se darem ares de sábios... Nāo. Rezo sem palavras, no meu grande panteismo, na perpétua adoraçāo das cousas; e, na minha miserabilissima e falha ciência sei positivamente que há alguma cousa que eu não sei"... E conclui: "é em nossa superenervação, é em nosso idealismo sem fadigas e é na nossa perpétua ânsia do belo que eu adivinho e sinto o que nāo sei. Singularíssimo ateu"... (19). As perspectivas que the davam o sentido poético e religioso da vida, o seu estado de insatisfaçāo e essa qualidade potencial que o levava a preferir a incerteza ao instinto infalivel, a flexibilidade à concentração juntavam-se tôdas sôbre êsse largo horizonte que Paul Claudel descobriu em Rimbaud, e se encontra em Euclides: "um mistico em estado selvagem".

Mas êsse mistico que vivia, no seu panteismo, na perpétua adoraçāo das cousas, tinha "a doce religião da Natureza amiga". segundo o belo verso de Vicente de Carvalho, e possuia em alto grau "o sentido do meio cósmico, a intuição da anima rerum, muito desenvolvidos, como lembra Almeida Magalhães, nos povos orientais, pela fixaçāo milenar no seu quadro regional, e paupérrimos entre nós americanos, ainda recentemente transplantados". Se a êsse sentimento telúrico que fêz de Euclides um "genius loci", uma "alma de eterno enamorado da natureza"; se a êsse sentido

(19). - In Euclides da Cunha a seus amigos. Cartas, a Araripe Junior, 9-3-1903, pg. 88, e 30-3-1903, pg. 95; a Alberto Rangel, 20-3-1905, pg. 163; a Otaviano Vieira, 5-11-1908, pg. 221; a Coelho Netto, 22-11-1903, pg. 112-113. 
agudo das relaçóes entre o homem e o seu habitat, que lhe permitiu fixar os dois tipos do sertanejo, - o caucheiro e o seringueiro, ligados, nos seus destinos, a dois vegetais, acrescentarmos o amor à sua terra e à sua gente, como nenhum outro o teve igual, (20) será fácil compreender a sedução invencivel que sôbre êle exerciam as nossas paisagens, os caudais e as cachoeiras, a terra árida e os sertões, as selvas e as montanhas. "Caminheiro infatigável e destemeroso que palmilhava as aspérrimas estradas sertanejas"; que se movia, como em seu próprio elemento, na selva escura e nas solidões encharcadas; que sonhava, como se lhe fôsse um privilégio, com as expedições à Hiléia amazônica, sem lhe temer nem - terror do nome, nem o mistério de suas lendas, nem o perigo mortal que pesava sôbre os viajantes e os exploradores, - o espectro da malária, Euclides apareceu para nos mostrar o verdadeiro semblante do pais, a um tempo contraditório e caótico, e uma das faces, - a face rude e sombria, voltada para o lado em que se põe - sol, tostada pela canícula e castigada pelos ventos ríspidos dos Andes. O que o atraia e lhe fazia vibrar os nervos, era a batalha da água com a terra, naqueles campos imensos de inundação, a batalha da árvore nas florestas densas, pela conquista do ar e da luz, a batalha do homem com a natureza hostil, para sobreviver e subjugá-la, "nesse mundo estremecido pelo fragor da germinaçāo". O que o arrebatava quase como uma fôrça magnética, a cuja influência nāo podia subtrair-se, era êsse habitat portentoso, de que se alegra ter já, em Manáos, descoberto o traço essencial, - "uma terra (escreve Euclides a José Verissimo) que se está preparando para o homem, para o homem que a invadiu fora de tempo, impertinentemente, em plena arrumaçāo de um cenário maravilhoso". "Estou a dois passos do deserto (anuncia de Manáos a um jovem bacharel) e às vésperas de uma viagem inçada de tropeços, dessas em que a gente leva carta de prego para o desconhecido." E que viagem seria essa? A partida para o alto $\mathrm{Pu}$ rús, pela qual esperava com anciedade e que êle mesmo considerava "o seu maior, o mais belo e arrojado ideal" (21).

Era êsse um encantamento de que nunca se cansava e que nenhuma glória conseguiria quebrar. Para a terra inhóspita e bravia é que tinha sempre voltadơs os olhos e o coraçāo. Em Guarujá alegra-se, ao receber uma carta de José Verissimo que lhe fortalece as esperanças na realizaçāo do seu ideal de bandeirante. "Estou (diz êle) cada vez mais animado a levá-lo por diante. Que melhor serviço poderia prestar à nossa terra? Além disso, nāo desejo a Europa, o boulevard, os brilhos de uma posição; desejo o

(20). - Almeida Magalhães - Euclides da Cunha - in "O Istado de São Paulo", de 15 de agosto de 1934.

(21). - In Euclides da Cunha a seus amigos. Cartas, a José Veríssimo, 13-1-1905 , pg. 14J; ; ao Dr. Edgard Jordão, 22-1-1005, pg. 148. 
sertăo, a picada mal gradada, e a vida afanosa e triste do pioneiro". De volta de sua expedição ao Purús, em que pensaria Euclides? A minha maior aspiração (escreve da cidade maravilhosa a Alberto Rangel) "seria deixar de uma vez êsse meio deplorável, com suas avenidas, seus automóveis, os seus smarts e as suas fantasmagorias de civilizaçāo pesteada". Nāo se conforma com a vida de cidade, em que parece sofrer de um desajustamento irremediável: a Rangel confessa-se desolado "com a pasmaceira trágica que há neste pais que esperneia, galvanizado, na Praia Vermelha e morre de fome nos sertões". Inquieta-se, ao lhe virem às mãos, dêsse amigo, em Paris, cartões postais "sinceramente admirativos do velho mundo". Penso com tristeza, responde-lhe Euclides, que êles te estejam apagando na alma a lembrança de nossa rude e. formosissima terra. Precisas reagir (aconselha a Rangel) contra. a feitiçaria da Velha tôda ataviada de primores e que, afinal, não vale a nossa pátria tāo cheia de robusta e esplêndida virgindade". Se a Rangel que lhe manda impressões fugitivas, em cartões rápidos, instantâneos, pede "noticias mais amplas dêsse "París mirabolante e fantástico", nāo deixa de acrescentar, dêsse París, "que nunca verei... nem tenho desejos de ver". A Francisco Escobar, exclama, com a sua incurável nostalgia do interior: "Que saudades do meu escritório de folhas de zinco e sarrafos da margem do Rio Pardo! Creio que, se persistir nesta agitação estéril, nāo. produzirei mais nada de duradouro". Ao remeter a José Veríssimo a fotografia de um grupo, apanhado na ilha dos Búzios, em que. figuram pessoas de grande projeçāo na época, pondera ao amigo. que, no extremo e em destaque, "está um animal bem superior a. todos os outros, um pescador da ilha, rija e empertigada figura de - piraquara robusto". Se, afinal, se de alguma cousa se envaidece, com a publicaçāo de "Os Sertões", é do livro "Inferno Verde". de Alberto Rangel: "é o livro do meu primeiro discípulo (escreve a Vicente de Carvalho), alentando-me a convicçāo de que abri uma picada, levando a outros rumos o espírito nacional... Que infinito prazer para um antigo engenheiro de estradas" (22).

Mas, com todo êsse profundo sentimento brasileiro, êsse deslumbramento pela terra e encanto enternecido pela sua gente, o escritor poderoso, "contemplador enamorado dos rios largos e das lagoas melancólicas", como the chamou Coelho Netto, pintor de paisagens e caracteres que retratou no jagunço, segundo lembra Oliveira Lima, "a nossa mais autêntica e desamparada população nacional", elevava-se acima e além das fronteiras, para admirar e amar tudo e todos em que via palpitar a centelha da inteligência,

(22). - In Euclides da Cunha a seus amigos. Cartas, a José Veríssimo, 7-7-. -1904, pg. 128: a Francisco Escobar, 8-4-1908. pg. 205; a Alberto Rangel, 20-9-1008, pg. 216, e 10-12-1907, pg. 199; a Jose Veríssimo, 31-8-1004, pg, 132; a Vicente de Carvalho, 8-9-1908, pg. 215. 
a fôrça do gênio criador ou a grandeza do coraçāo humano. Dir-se-ia que, quanto mais fincava suas raizes vorazes no humus da terra e da vida nacional, tanto mais se lhe alargava o espirito e se the dilatava a visāo, no espaço e no tempo, para horizontes ilimitados. Êste, o último aspecto, e o mais desconhecido, do humanismo de Euclides, - o seu espírito universal, que é como um rio cuja torrente viva e profunda se precipitasse sob a superfície de águas geladas. Amando o seu país, no que tem de mais autêntico e original, com um amor apaixonado e uma lucidez nāo conformista, mas "sem lamúrias de superstições patrióticas", esforçou-se Euclides a vida inteira, numa luta sem desmaios, por revalorizar a pessoa humana, por lhe defender e exaltar a dignidade, a liberdade de espírito, de critica e de criaçāo, como por propagar a fé tanto nas energias acumuladas de seu povo quanto na solidariedade continental e humana e no destino superior da civilizaçāo. No culto ocidental da inteligência, nessa "resoluçāo misteriosa que o homem europeu adotou, como observa Ortega y Gasset, de vivir de su inteligencia e desde ela", tinha Euclides a ocasiāo de autênticas comunhões com a vida nacional e universal. A inteligência, se nāo é o laço ecumênico, eterno, dos homens, porque freqüentemente se transforma numa fonte de conflitos e divergências, o culto que lhe votava Euclides, constituia, para êle, a ponte de ligação com que mais fàcilmente se comunicava com os homens dentro e além das fronteiras nacionais. Nas suas lutas, e na perspectiva de derrotas, orgulhava-se por ter, "em compensaçāo, a seu lado a elite dos homens de talento"; admirava Gastāo da Cunha, porque "na enorme decrepitude dessa gente, realizava ainda o grande milagre de ter espírito" e, por isto, se entristecia com a sua partida para Assunçāo, que "lhe fazia o efeito de um despovoamento": inquietava-se com os assaltos da mediocridade a tôdas as posições, porque "nada via (declara êle) de maior interêsse para a comunidade que o primado incondicional das competências"; e, quando morre Machado de Assis, se conforta, na sua desolaçāo, com as homenagens excepcionais que lhe foram prestadas, - "as maiores que ainda se fizeram neste país a um escritor, e em que se observou, pela primeira vez, entre nós, abalando tôdas as camadas sociais, o prestígio da magistratura superior do pensamento". Nāo é menor o seu entusiasmo pela inteligência, quando se encontra pela primeira vez, no Itamarati, com Guglielmo Ferrero, o evocador da antiguidade romana, que nāo tardou a desiludi-lo, ou com George Dumas, com quem diz ter passado "a tarde mais ilustre de sua vida", ou quando evoca os grandes intelectuais do Perú e, especialmente, Riva Aguero, o jovem historiador "que tem talento por todos os peruanos juntos" e que tomara posiçāo contrária à de Euclides na questāo de limites entre o Perú 
e a Bolivia. "Felizmente, exclama Euclides, antagonistas daquele porte respeitam-se, temem-se e amam-se" (23).

Êste, o homem que foi Euclides da Cunha, tantas vêzes incompreendido, mal interpretado, hostilizado. Mas nāo lhe bastou, em sua curta vida de 43 anos, - tāo curta como bela e fecunda, ter sido sempre preterido, nas suas mais legítimas ambições, "vendo pular na frente quanto felizardo vadio" medrava neste país, em que, a despeito de seu notável valor e da alta reputaçāo que grangeara, nāo conseguiu, senāo à custa de enorme esfôrço, uma situaçāo estável, com a sua nomeaçāo para o Colégio Pedro II, a 14 de junho de 1909, dois meses antes de seu trágico desaparecimento. Nāo lhe bastaram os sofrimentos angustiantes e os trabalhos, heróicos e ascéticos, que lhe amarguraram os últimos anos e lhe arruinaram a saúde, tirando-lhe até a possibilidade de acudir ao pai enfermo, e dispensar-lhe os cuidados e desvelos que reclamava o seu estado e lhe prestaria, "se o destino (sāo palavras de Euclides) não andasse até hoje a jogar-me como peteca para êsse mundo além. Sòmente agora (conclui, mais uma vez iludido) descansou o bárbaro". Descansava (comenta Francisco Venâncio Filho) para fuzilá-lo no mês seguinte... Todos êsses abalos e essas comoções tinham de ser seguidos de um epilogo tremendo. Ele havia sido arrebatado numa torrente em que outros nāo perderam - pé e em que pereceu tràgicamente, mas teve a fortuna de conservar intacta a sua dignidade. Em certo dia, a sua exaltaçāo cresceu. Era como um delírio e uma alucinação, após o desfalecimento invencivel, a sensaçāo de esvanescimento progressivo, o abatimento na vertigem. Ele se tinha imposto, nos últimos tempos, privações terriveis das quais seu estado de super-excitaçāo o havia impedido de sofrer todo o pêso e entrever todo o perigo. A sua marcha para o desconhecido foi com uma cegueira voluntária... "Quem definirá (escreveu naquele mesmo ano a Vicente de Carvalho) quem definirá um dia essa Maldade obscura e inconsciente das cousas que inspirou aos gregos a concepçāo indecisa da Fatalidade? Às vêzes (acrescenta êle) julgo necessário um Newton, na ordem moral, para fixar numa fórmula formidável o curso inflexivel da Contrariedade" (24). Mas nāo foi só. Pobre Euclides! Persistiu a tragédia (lembra Almeida Azevedo) perpetuan-

(23). - In Euclides da Cunha a sens amigos. Cartas, a Araripe Junior, 27-2-1903, pg. 86; a Francisco Escobar, 24-7-1903, pg. 105, e 17-11-1906, pg. 1S2: a Oliveira Lima. 13-1.1-1908, pg. 223: a Regueira Costa (sem data), pg. 218. e a Domício da Gama. 16-11-1907. pg. 195.

(24). - In Euctides da Cunha a seus amigos. Cartas, a Francisco Escobar, 31-12-1907. pg. 201; a Otaviano Vieira, 6-7-1909, pg. 243; a Vicente de Carvalho. 10-2-1909. pg. 229 . 
do-se nas vidas de seus dois filhos, abreviando-as da mesma sorte. Solon e Euclides (o Quidinho da familia) morreram também baleados... Dir-se-ia que o mais inexorável dos destinos nāo se contentou em desgraçá-lo em vida, mas precisou prender nos seus tentáculos, - fatalismo cruel, aos seus entes mais queridos "num bracejar de torturas", transformando o mais genial de nossos escritores na mais ilustre vitima do destino" (25).

Posteridade, reflete melancòlicamente Euclides da Cunha, "posteridade; afinal o único prêmio certo e digno, embora nāo sentido, dos verdadeiros lutadores". Posteridade, sim, o único prêmio à altura do escritor e do homem, cuja vida foi um aspecto da nossa própria vida nacional e que foi o orgulho e a glória de uma época desaparecida e o precursor de uma nova éra de que apenas se distinguem os primeiros albores na fimbria distante do horizonte. Ele nunca teve, por isso, nenhuma pressa de ter sua estátua: pode-se esperar quando se é imortal. Quando em 1903, da redaçāo d'"O Estado de S. Paulo", aonde chegava, com o alvoroço de todos, a primeira grande repercussão de "Os Sertões", saiu êsse homem de 37 anos, "com o enorme estonteamento (como êle o confessa) de um recruta transmudado repentinamente em triunfador", estava longe de supor que, de fato, maior do que o extraordinário sucesso literário era a significaçāo, ainda apenas entrevista, da grande obra com que abriu, segundo o reconhece já no fim da vida, novos rumos ao espirito nacional. Ele passou pela vida (permiti-me empregar as palavras com que se referiu a Gregório de Mattos e que a êle se podem aplicar com rigorosa exatidāo) "obedecendo à fatalidade mecânica de uma resultante intorcivel: incorrigivel, rebelde sempre à visāo estreita dos que pensavam morigerá-la, como se houvesse preconceitos ou regras para êsses avant-coureurs da nacionalidade, titeres privilegiados, arrebatados pelas leis desconhecidas da história". A fé superior de que viveu, alimentada nas fontes nacionais e humanas, e em que sorveu a sua fôrça de pensar e de agir, nāo se enganou. Foi altiva e nobre, embora profundamente infeliz, a inspiraçāo que fêz a dignidade de sua vida e faz a honra de seu nome. Tão nobre e altiva, e tão rica de conteúdo moral, que Francisco Venâncio Filho, apanhando-lhe, com uma intuiçāo divinatória, o sentido profundo dessa grande vida. "do próprio culto à memória de Euclides, poude fazer surgir, como observou Roquette Pinto, um movimento de educaçāo civica sem paralelo no Brasil". Neste tempo tāo cheio de obscuridades e incertezas, de tortuosidades e misérias, se quizermos, de fato, assentar na educaçāo da mocidade as noções e virtudes morais, e elevar ao primeiro plano o cuidado da dignidade e da honra, nāo temos nada de melhor do que seguir a mais in-

(25). - Slvaro Augusto Almeida Azevedo - Tm contato com lcuclides, in "O Estado de S. Paulo". 15 de a.gôsto de 194 (i. 
tensa de tôdas as luzes, - aquela que brilha de tôdas as partes na vida dos grandes homens aos quais se reuniu êsse "pioneiro da nacionalidade triunfante", êsse gênio da raça, na sua existência, desigual e revolta, como a nossa própria natureza, feita de doces planuras e de relevos absurdos, de fôrças hostis e dispersivas mas também de poderosas fôrças de atraçāo.

\section{FERNANDO DE AZEVEDO.}

Professor de Sociologia da Faculdade de Filo8ofia, Ciências e Letras da Universidade de São Paulo. 